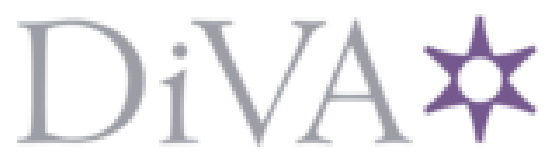

http://www.diva-portal.org

\title{
Postprint
}

This is the accepted version of a paper presented at Academic MindTrek 2015, 22-24 September 2015, Tampere, Finland.

Citation for the original published paper:

Nyström, T., Mustaquim, M. (2015)

Finding Sustainability Indicators for Information System Assessment.

In: Turunen, M (ed.), Proceedings of the 19th International Academic MindTrek Conference

(AcademicMindTrek '15) (pp. 106-113). New York: Association for Computing Machinery

(ACM)

http://dx.doi.org/10.1145/2818187.2818278

N.B. When citing this work, cite the original published paper.

Permanent link to this version:

http://urn.kb.se/resolve?urn=urn:nbn:se:uu:diva-261098 


\section{Finding Sustainability Indicators for Information System Assessment}

\author{
Tobias Nyström \\ Uppsala University \\ Uppsala, Sweden \\ tobias.nystrom@im.uu.se
}

\author{
Moyen M. Mustaquim \\ Uppsala University \\ Uppsala, Sweden \\ moyen.mustaquim@im.uu.se
}

\begin{abstract}
Nowadays, the importance of sustainability is persuading novel shifts in everyday life. This diversity makes it significant and challenging for sustainability to be quantified and measured. While the existence of perfect sustainability indicators is relatively unreasonable, they have important pragmatic roles in quantification and measurement by bridging sustainability's three pillars. Information system (IS) and sustainability are popular research areas, which clearly reflect the divergent and multidimensional role of sustainability. Despite this importance, defining the right sustainability indicators for IS is imperceptible. In this paper, we have identified sustainability indicators for IS using previous theoretical frameworks where universal design (UD) and its advance concept were used. Followed by this, a framework of IS sustainability indicators were proposed. The indicators were shown in the form of a design space arrangement, which could play significant roles in assessing sustainability for IS.
\end{abstract}

\section{Categories and Subject Descriptors \\ K.4.m. [Computers and Society]: Miscellaneous.}

\section{General Terms}

Theory.

\section{Keywords}

Sustainability; Sustainability Measurement; Sustainability Indicators; Information System Sustainability Assessment.

\section{INTRODUCTION}

The concept of sustainability is complicated, as Mulvihill and Milan [23] entitled the problems associated with sustainability to be "an uninspiring abstraction". Because of

"Copyright is held by the owner/author(s), 2015. Publication rights licensed to ACM. This is the author's version of the work. It is posted here by permission of ACM for your personal use. Not for redistribution. The definitive version was published in AcademicMindTrek '15, September 22 - 24, 2015, Tampere, Finland http://doi.acm.org/10.1145/2818187.2818278 ". this multifaceted construct, a wide range of interest to be able to sustain beyond different economic and commercial successes became a major challenge for organizations acting in today's society. Because the economic interest of sustainability cannot be enough for organizations anymore, and understanding the social and environmental impact is equally important. A holistic view of sustainability can thus reflect different new opportunities from where organizations can benefit by creating sustainable corporate strategies. At the same time in search of different sustainability goals the importance of IS was discussed in numerous literature. The role of IS in an ecological sustainability context is to curb pollution and reduce costs through automation, which was addressed by Chen et al. [4], where the prospect of IS to completely transform the organization was discussed. Different IS solutions showed indirect effects on saving energy and empirical evidence supports IS being able to decrease emissions [18]. Since information technology as a globalization driver is dematerializing different value added activities [19], the IS as an application of different information technologies have a major influence in defining complex sustainability goals. However, only having a sustainability vision is not sufficient for organizations since vision driven sustainability has limited or no impact on the business model to reflect sustainability impacts in the form of different strategies. Therefore, in the end vision, driven sustainability practice would make organizations fail to attain true values of sustainability. However, for a transformation of vision into strategic scale to happen, identification and measurement of different sustainability factors are crucial.

This brings us to the subject of sustainability indicators. Sustainability indicators could reveal the inter-connectivity of different sustainability dimensions, and ease the process of sustainability quantification and thereby direct us towards a better future. As Wefering et al. [31] suggested the quantitative approach of evaluating sustainability to be superior a qualitative approach, hence understanding and selecting appropriate sustainability indicators are vital for organizations that are using IS. Moreover, emphasis was given on quantifying different qualitative statements regarding sustainability (e.g. See Dalsgaard et al. [6]). By successfully selecting indicators, their quantification can help the organization to create different targeted values. At the same time, there is a risk, since poorly chosen indicators can cause serious negative consequences [22], e.g. GDP could be used for measuring sustainable progress but would also increase due to cleaning after an oil catastrophe. Despite the availability of numerous sustainability indicators, they reflect the results 
of specific case studies through which the feasibility of using the indicators is contextually reflected. One example is when Azapagic and Perdan [1] identified different indicators and proposed a framework explicitly aimed towards sustainable development in the industry. However, despite the crucial significance of IS in regard to sustainability it is not yet evident which indicators should be considered for measuring sustainability for IS.

This builds up the underlying rationale behind the research question in this research, "What are the appropriate indicators that could be quantified for measuring sustainability of an IS?" The authors answer this question, they have derived a new set of sustainability indicators for IS, by using previous theoretical frameworks (Section 3). The indicators are briefly discussed in this section, followed by a proposed theoretical framework. In Section 4 we illustrate and discuss a design space for IS sustainability indicators. We furthermore presented a concrete background Section 2 introducing sustainability indicators, their importance, and relation with IS. Finally, in Section 5, extensive discussions with future work potentials are presented and conclusions are given in Section 6.

\section{BACKGROUND}

\subsection{Sustainability Indicators}

Understanding the right indicators and their interconnections is a key in the sustainability assessment work. The quantitative approach of sustainability assessment is especially useful detecting different critical features associated with product and process, and another benefit with indicators taken from quantification is their ability to be easily understood and graphically illustrated for conceptualization $[16,33]$. By interpretation of different variables, we assign them a meaning and give them significance that goes beyond its face value taken from observation [13]. Indicators are thus variables that summarize and simplify reality's complexity in order to give important properties of the studied systems opposed to other variables that give isolated or superficial characteristics of the studied system $[2,14]$. An indicator of good quality should be relevant, reliable, and easy to understand. In some areas like agriculture, transportforestry, industry, and energy etc., there exists specific sets of indicators that are in use or have been developed. Gallopin [13] predicted an increased need to assess the effectiveness of policies and to monitor progress, something that is still true and perhaps even more important and imminent; we need to take action now. Some predict that we are now at a crossroads, and if action is not taken immediately to counteract global warming, future generations will suffer and not be able to meet their own needs [5]. Supporting this dire situation are simulations of future global warming that shows alarming future trends [28].

UN Department of Economic and Social Affairs (DESA) made an attempt and effort to develop sustainable indicators [29], they published a list of approximately 140 indicators that covers economic, social, environmental and institutional aspects of sustainable development. Devuyst et al. [9] define sustainability assessment as "...a tool that can help decision-makers and policy-makers decide which actions they should or should not take in an attempt to make society more sustainable". There are no universal indicators that can be used in all contexts of sustainability. The prag- matic aspect of indicators is important and need consideration, since the indicator is given significance by the public and decision-makers. Indicators could be seen as our link to the world [2], this also gives hope since if we successfully strengthen sustainability values and let them permeate society a change could happen. Indicators are thus used for measurement, improvement of decision-making, or to monitor current progress and goal achievement. Successful identification of indicators should thus reflect the close connection of the three dimensions (social, environmental, and economic) of sustainability.

\subsection{Sustainability Assessment and Importance of Indicators}

The IS for sustainability could use indicators for policy making of IS or the identifiers could be used to compare and evaluate the IS impact on established sustainability goals and policies. Some pragmatic considerations and properties of universal requirements for indicators taken from Harger and Meyer [15] and Gallopin [14] are: The indicator must be measurable otherwise it cannot get a value i.e. if something is not observable, it is not an indicator. By monitoring or measuring, data will evidently become obtainable, if not already available. To make indicators valid, they must be clear, standardized, and transparent in the data gathering process. Available for monitoring and building means that different indicator must exist and it should be possible to determine trends based on these indicators. Cost effectiveness is an important criterion for indicators or sets of indicators. Indicators should be approved and have a commitment by decision-makers at appropriate level otherwise they will not have any influence on decisions. An indicator that creates participation and public support is desirable since then they have the possibility to influence society at large.

\subsection{IS for Sustainability and Indicators}

No clear definition of indicators in research exists, instead, it differs depending on the author (sometimes the same author define indicators differently that could end up in contradictory ways). This shows the contradictions and ambiguities regarding the fundamental concept of indicators in general. This for sure holds true for indicators in the context of IS for sustainability. The design of IS for sustainability is important because if it is poorly conducted it could result in environmental and social degradation [26], the importance increases since IS becomes more and more persuasive and definitely have an impact on individuals, organizations, societies and governments. The persuasiveness of IS contributes to its importance since it could be designed for achieving different sustainability goals. By using the IS for sustainability the impact of different processes on sustainability could be minimized or reversed. In a framework development process a set of sustainability indicators could be crystallized, that would display if they reflect the full range of sustainability concerns that needs to be considered [10]. Since IS for sustainability cold be used in different contexts, there would be no all-encompassing remedy and in vain to try finding indicators that would always be valid. 
Table 1: Sustainable system design principles and their associated different indicators

\begin{tabular}{|c|c|c|c|}
\hline $\begin{array}{c}\text { Sustainable IT } \\
\text { System Design } \\
\text { Key properties }\end{array}$ & Social & $\begin{array}{c}\text { Environ- } \\
\text { mental }\end{array}$ & Economic \\
\hline $\begin{array}{c}\text { Nature as } \\
\text { a mentor } \\
\text { in design }\end{array}$ & $\begin{array}{c}\text { Social } \\
\text { Equity }\end{array}$ & $\begin{array}{c}\text { Natural } \\
\text { resource } \\
\text { balancing }\end{array}$ & $\begin{array}{c}\text { Energy } \\
\text { consumption }\end{array}$ \\
\hline $\begin{array}{c}\text { Resource } \\
\text { reduction } \\
\text { during design }\end{array}$ & $\begin{array}{c}\text { Increased } \\
\text { error } \\
\text { tolerance }\end{array}$ & $\begin{array}{c}\text { Renewable } \\
\text { resources }\end{array}$ & $\begin{array}{c}\text { Risk } \\
\text { selection }\end{array}$ \\
\hline $\begin{array}{c}\text { Practice } \\
\text { design } \\
\text { for majority }\end{array}$ & $\begin{array}{c}\text { Diversification } \\
\text { approach }\end{array}$ & $\begin{array}{c}\text { Reduction of } \\
\text { consumption }\end{array}$ & $\begin{array}{c}\text { Stakeholder's } \\
\text { gap } \\
\text { reduction }\end{array}$ \\
\hline $\begin{array}{c}\text { Simplicity and } \\
\text { flexibility for } \\
\text { easy customization }\end{array}$ & $\begin{array}{c}\text { User } \\
\text { satisfaction }\end{array}$ & $\begin{array}{c}\text { Behavior } \\
\text { modification }\end{array}$ & $\begin{array}{c}\text { Error } \\
\text { reduction }\end{array}$ \\
\hline $\begin{array}{c}\text { Adverse effect } \\
\text { reduction and } \\
\text { alternation }\end{array}$ & $\begin{array}{c}\text { Cumulative } \\
\text { contentment }\end{array}$ & $\begin{array}{c}\text { Ecological } \\
\text { constraints }\end{array}$ & $\begin{array}{c}\text { Productivity } \\
\text { increase }\end{array}$ \\
\hline $\begin{array}{c}\text { Holistic thought of } \\
\text { synergies and } \\
\text { emergent properties }\end{array}$ & $\begin{array}{c}\text { Social } \\
\text { transparency }\end{array}$ & $\begin{array}{c}\text { Complex } \\
\text { decision } \\
\text { implication }\end{array}$ & $\begin{array}{c}\text { Organizational } \\
\text { structure } \\
\text { merging }\end{array}$ \\
\hline
\end{tabular}

Table 2: Subjective and objective classification of the identified indicators

\begin{tabular}{|c|c|}
\hline Subjective Indicators & Objective Indicators \\
\hline Social transparency & Energy consumption \\
\hline User satisfaction & Risk selection \\
\hline Stakeholder's gap reduction & Error reduction \\
\hline $\begin{array}{c}\text { Organizational structure } \\
\text { merging }\end{array}$ & Productivity increase \\
\hline Diversification approach & Cumulative contentment \\
\hline Increased error tolerance & Natural resource balancing \\
\hline Ecological constraints & Renewable resources \\
\hline $\begin{array}{c}\text { Complex decision } \\
\text { implication }\end{array}$ & Reduction of consumption \\
\hline Behavior modification & Ecological constraints \\
\hline
\end{tabular}

\section{A SUSTAINABILITY INDICATOR FRAMEWORK FOR IS}

Mutsaquim and Nyström [24] showed a way of extending the traditional use of UD principles by creating sustainable IT system design principles, this was done by juxtapose sustainability and UD together to produce six unique design principles. Fiksel [11] has in his research discussed different conventional sustainability indicators. The underlying theoretical framework of this paper is based on these two research works. In Table 1, a matrix illustrates different design principle properties of a sustainable IT system that were considered and then structure into their corresponding social, economic and environmental dimensions of sustainability. Since these dimensions were suggested by Welford [32] to be the three "closely connected issues" for sustainable development. For each corresponding design principle's property the indicators that should be considered to measure within the context of the three dimensions of sustainability is shown in Table 1. In Table 2, the identified indicators are classified into the categories of subjective and objective indicators. These indicators are shown in a relationship with different indicators from Fiksel [11] in Table 3 under the three dimensions of sustainability. In section 3.1 to 3.3 , these indicators are described. A theoretical framework labeled "Sustainabil-
Table 3: A comparison matrix of different identified indicators with Fiksel [11]

\begin{tabular}{|c|c|c|c|c|}
\hline \multirow{2}{*}{$\begin{array}{c}\text { Identified } \\
\text { Indicators for } \\
\text { IT System } \\
\text { Design }\end{array}$} & \multirow{2}{*}{$\begin{array}{l}\text { Corresponding } \\
\text { Indicators from } \\
\text { Fiksel [11] }\end{array}$} & \multicolumn{3}{|c|}{ Contexts of Sustainability } \\
\hline & & Social & Economic & $\begin{array}{c}\text { Environ- } \\
\text { mental }\end{array}$ \\
\hline Social Equity & $\begin{array}{c}\text { Material } \\
\text { consumption }\end{array}$ & & $\mathrm{X}$ & $\mathrm{X}$ \\
\hline $\begin{array}{c}\text { Increased error } \\
\text { tolerance }\end{array}$ & Quality of life & $\mathrm{X}$ & & \\
\hline $\begin{array}{l}\text { Diversification } \\
\text { approach }\end{array}$ & Quality of life & $\mathrm{x}$ & & \\
\hline $\begin{array}{c}\text { User } \\
\text { satisfaction }\end{array}$ & Peace of mind & $\mathrm{X}$ & & \\
\hline $\begin{array}{c}\text { Cumulative } \\
\text { contentment }\end{array}$ & $\begin{array}{c}\text { Recycling } \\
\text { revenue }\end{array}$ & $\mathrm{x}$ & & $\mathrm{x}$ \\
\hline $\begin{array}{c}\text { Social } \\
\text { transparency }\end{array}$ & Quality of life & $\mathrm{x}$ & & \\
\hline $\begin{array}{c}\text { Natural } \\
\text { resource } \\
\text { balancing }\end{array}$ & $\begin{array}{c}\text { Material } \\
\text { consumption }\end{array}$ & & $\mathrm{X}$ & $\mathrm{X}$ \\
\hline $\begin{array}{c}\text { Renewable } \\
\text { resources }\end{array}$ & $\begin{array}{c}\text { Material } \\
\text { consumption }\end{array}$ & & & $\mathrm{X}$ \\
\hline $\begin{array}{l}\text { Reduction of } \\
\text { consumption }\end{array}$ & $\begin{array}{c}\text { Raw material } \\
\text { cost }\end{array}$ & & $\mathrm{X}$ & $\mathrm{x}$ \\
\hline $\begin{array}{c}\text { Behavior } \\
\text { modification }\end{array}$ & Quality of life & $\mathrm{X}$ & $\mathrm{X}$ & $\mathrm{X}$ \\
\hline $\begin{array}{l}\text { Ecological } \\
\text { constraints }\end{array}$ & $\begin{array}{c}\text { Material } \\
\text { consumption }\end{array}$ & & & $\mathrm{X}$ \\
\hline $\begin{array}{c}\text { Complex } \\
\text { decision } \\
\text { implication }\end{array}$ & Peace of mind & $\mathrm{x}$ & $\mathrm{x}$ & \\
\hline $\begin{array}{c}\text { Energy } \\
\text { consumption }\end{array}$ & $\begin{array}{c}\text { Energy } \\
\text { consumption }\end{array}$ & & & $\mathrm{X}$ \\
\hline Risk selection & $\begin{array}{c}\text { Product } \\
\text { disposition cost }\end{array}$ & & $\mathrm{X}$ & \\
\hline $\begin{array}{l}\text { Stakeholder's } \\
\text { gap reduction }\end{array}$ & Relationship & & $\mathrm{x}$ & \\
\hline $\begin{array}{c}\text { Error } \\
\text { reduction }\end{array}$ & Quality of life & $\mathrm{X}$ & & \\
\hline $\begin{array}{c}\text { Productivity } \\
\text { increase }\end{array}$ & Operating cost & & $\mathrm{X}$ & \\
\hline $\begin{array}{l}\text { Organizational } \\
\text { structure } \\
\text { merging }\end{array}$ & Relationship & & $\mathrm{X}$ & \\
\hline
\end{tabular}

ity indicators framework for IS" built on the sustainability indicators are proposed and discussed in section 3.4.

\subsection{Social Indicators for IS}

Below is a description of our identified social sustainability indicators.

\section{Social Equity}

Life-cycle assessment could estimate the value of processes. This will be impacted by the resource use of the IS from the cradle i.e. development of the system, to the grave i.e. the termination and closing of the system. The less material and resources that uses the lower will the impact on the environment is. Another dimension is the efficiency of the IS as a ratio for measuring what impacts we get from the input of one resource unit.

\section{Increased Error Tolerance}

Quality of life can be enhanced since it is affected by the breadth of product, and services that are offered to the user of IS. If the error tolerance is increased for the IS, more users would be able to use the system without too much worry about using the system and the impact on their quality of life would be positive. 


\section{Diversification Approach}

If a system uses a diversification strategy, it would also have a positive impact on the quality of life because an IS for sustainability would be applicable for more users compared to if the strategy had been the opposite i.e. to offer only one way to interact with the system.

User Satisfaction

Peace of mind and increased user satisfaction could be achieved by offering easy customization of the IS for sustainability. Simplicity and flexibility of the IS would make it beneficial for customization and increase the number of presumptive users that would use the system.

\section{Cumulative Contentment}

Recycling revenue would mean that the system minimizes resource use by recycling resources, or, when possible, reverse the impact of different processes. That would raise the possibility of cumulative contentment for users of the IS.

\section{Social Transparency}

Quality of life could be improved if the system gives transparency and shows synergies and associated emergent properties in an improved way through its design and use. This would increase the holistic thought process and have a positive impact on increasing the different sustainability goals of IS.

\subsection{Environmental Indicators for IS}

Our identified environmental sustainability indicators for IS are described below:

\section{Natural Resource Balancing}

Material consumption and the balancing of resources could be judged on, for example eco-efficiency, the use of hazardous material and the useful product life cycle. This balancing can be delicate and needs a lot of consideration to reflect on the pros and cons of materials that could be prompted by the IS.

\section{Renewable Resources}

Material consumption is very important as the choice of material can impact on to what degree the renewable resources will be used and thereby to what degree the sustainability of an IS would be achieved.

\section{Reduction of Consumption}

The raw material cost will influence the consumption. If the efficiency of material use is high, then the impact on sustainability will be lower and if the cost increases caused by high quality and sustainable material are used, then consumption will be reduced.

\section{Behavior Modification}

If the system offers simplicity and flexibility for customization, it would make the user feel more engaged with the IS and a behavior modification thus would be easier to do. In addition, the activity in the system should be impacted positively, and if more people are attracted then more people will follow others to use the system.

\section{Ecological Constraints}

Material consumption is crucial for dealing with ecological constraints, since some materials are very scarce and difficult to extract or be hazardous. This can initiate or increase different ecological constraints. The use of resources must be considered in the long run and implemented with strategies for the IS design for sustainability.

\section{Complex Decision Implication}

Peace of mind for users of an IS could be reached if a holis- tic thought is introduced and understood by the user of IS. This should give the user better knowledge of perceived risks of the system and increase the community trust towards the use of the system.

\subsection{Economic Indicators for IS}

Our identified economic sustainability indicators for IS are described below:

\section{Energy Consumption}

The traditional product energy analysis measures the energy needed to produce the service or the product [17]. Analysis of the total energy life cycle can be necessary to understand completely the impact that the IS would have on the environment, society and on the economic dimension during its use.

\section{Risk Selection}

Here, potential initial hidden costs must be considered e.g. the product disposition cost that perhaps is unknown initially since no real disposition is done yet. However, using life-cycle assessment should make it possible to relatively accurate estimate this type of costs.

\section{Stakeholder's Gap Reduction}

Relationships can possibly reduce the stakeholder's gap if users are retained and keep on using the system. This will also make fewer stakeholders keen to cause interventions and business interruptions, instead be committed to the sustainable goal.

\section{Error Reduction}

Stakeholder's quality of life will improve by reducing errors to a minimum (although a system can never be errorless). The satisfaction regarding the use of IS for sustainability will increase too, as well as the product/service availability with users increased knowledge.

\section{Productivity Increase}

Operating costs have an impact on productivity since the total costs of resources used by an IS would determine the productivity based on the output from the system. This is important to understand for the efficiency of the IS.

\section{Organizational Structure Merging}

The relationship between different stakeholders is important in order to reach efficient organizational structures, followed by a decrease in business interruptions caused by stakeholder interventions. It is important to find a balance in the organizational structure since a too hierarchical structure might fence off potential stakeholders since they could feel themselves unable to influence the system.

\subsection{Sustainability Indicator Framework}

Maruster et al. [21] showed four layers of sustainable IS design based on a classical service oriented-based architecture (application-, service-, and business process- layer) solution enhanced with a knowledge layer. The reason for the knowledge layer is that it allows the finding of the discrepancies between the (knowledge about) environment and IS, and facilitates the search for a solution. In Daly's [7] framework, a triangle illustrates the relationships of the three pillars of sustainability. Daly [8] on the other hand used "ultimate means" and "ultimate ends" to refer an ends-means spectrum, where "ultimate means" is low entropy energy/material and "ultimate ends" could be seen as "environment and equity in terms of human well-being" i.e. sustainability. Each intermediate level in the continuum is a means with respect to higher levels and an end with respect to lower categories. 


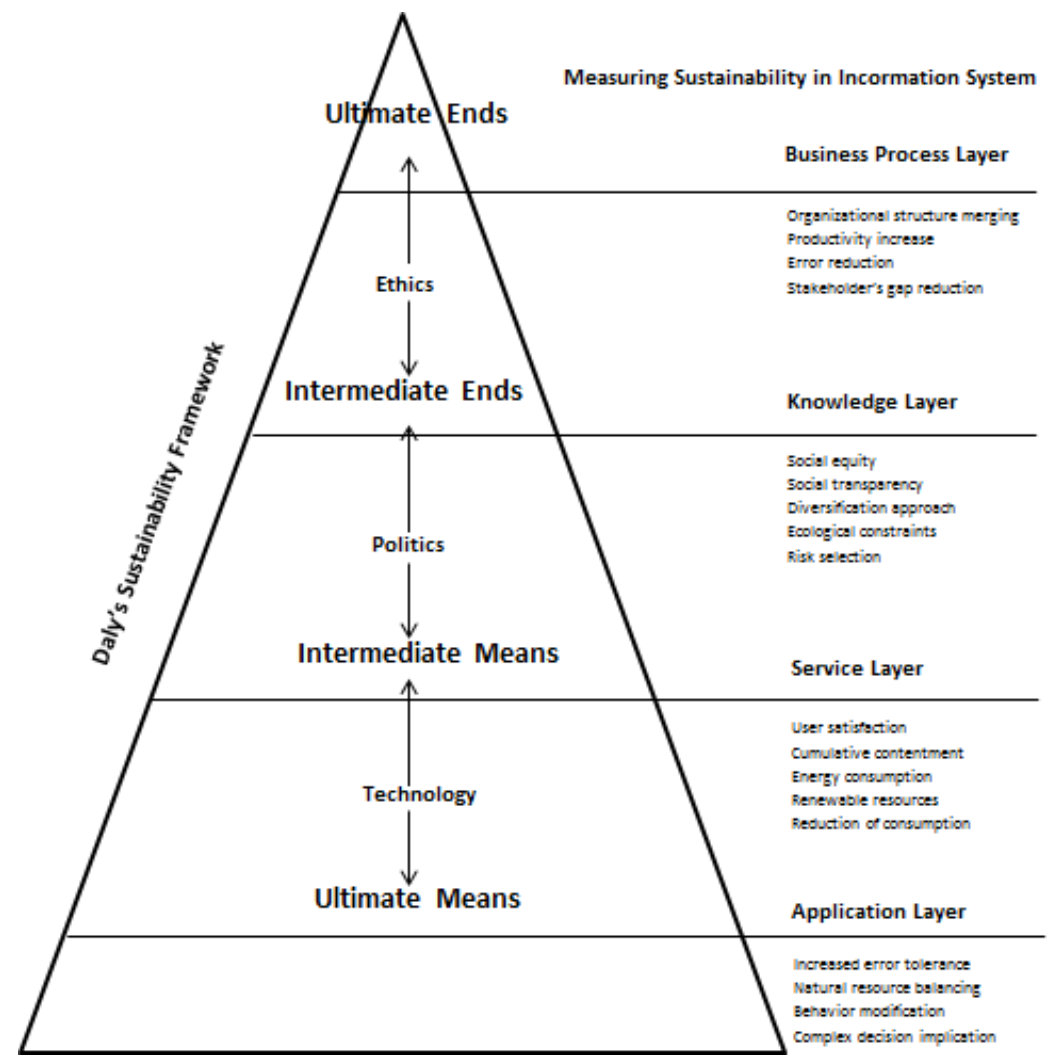

Figure 1: A Sustainability indicator framework for IS.

Since economists concentration on the intermediate levels of the spectrum, they do not include absolute limits in their consideration, because absolute limits can only be found in "ultimates" [8]. The terms "intermediate means" and "intermediate ends" in the middle of the triangle denotes economy. Technology, politics, and ethics were used as a mean of translation from "means" to "ends". By putting the economy in the middle, this framework emphasizes that economy is a way to achieve ultimate ends as we argued in this paper that, organizations should not only focus on the economy when they are dealing with achieving sustainability.

We, therefore, in Figure 1 (adapted from Meadows [22]) applied the triangle of Daly [7] by placing the four layers of sustainable IS design from Maruster et al. [21] to model a framework of sustainability indicators for IS. The four layers were mapped with the successive phases of the triangle where our identified indicators were categorized under each layer. The framework is described here.

At the bottom of the framework, we have ultimate means which corresponds to the application layer of the IS. The basis of transaction from social to economic phase is constructed here and technology plays the core role in this transfer. The intermediate means and intermediate ends are to reflect the economy. We have the service and knowledge layers structured within these two elements in the triangle. Associated indicators can define different inputs that are important for the economy pillar of sustainability. A transformation of different inputs to the implementation level as the form of output also takes place here. Complex decision makings and different expected outcomes involving politics are reflected as results. This transition can therefore be shown to be using politics. Finally, the ultimate ends are shown in the top of the triangle associated with the business process layer. Different indicators here reflect the desires that are seen as an ultimate goal and different ethical consideration can make this transition happen. One interesting way to interpret the framework can be to realize the effectiveness of different layers in the design and evaluation of IS for sustainability. For example, by considering the indicators from service layer, it could be understood if a specific factor needs transition to contribute towards sustainability without worrying the impacts from the application or knowledge layer. At the same time, it is possible to interpret which indicators need to put more emphasis on technology, ethics or politics. On the other hand, by trying to understand this, new indicators with their associated layer could be identified.

\section{PROPOSED DESIGN SPACE}

As the proposed framework can also be used to design IS for sustainability with the help of the associated indicators, it is important to understand how this could be done. A design space constitutes the conceptual space of possible design options and the design space for sustainable IS design can help us to understand this. On the other hand, how different indicators themselves could be discovered in an IS could also be important in order to successfully apply the proposed framework. Figure 2 shows a design space for IS sustainability indicators from which these issues could be realized. 


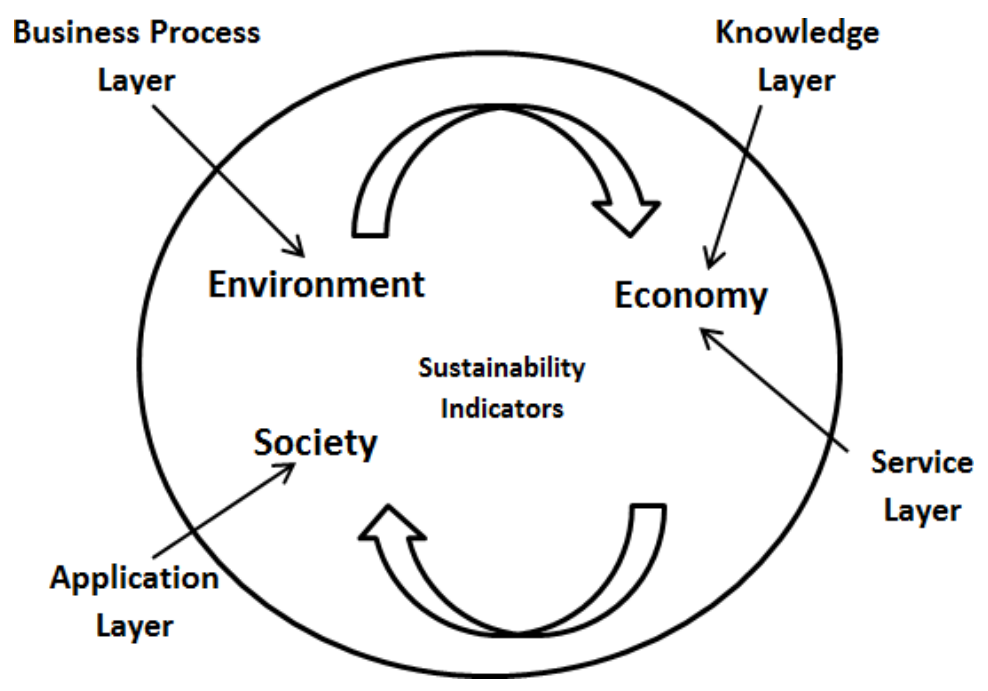

Figure 2: Sustainability indicator design space for IS.

In Figure 2, the four layers of IS are shown together with the three dimensions of sustainability in a cyclic process, followed by the proposed framework in Figure 1. The cyclic process can help identify different sustainability indicators for IS. Knowledge and understanding of existing indicators in this design space can be used to design an IS for sustainability. Different indicators take from the different layers of the IS design could be tested and evaluated to see if they are the correct choice for that specific layer in design. By iterating this, a better understanding of the IS for sustainability together with the associated complexity and multidimensionality of sustainability will be gained, and new indicators could be discovered in the process. Iteration is also important to change the design and adapt to changes, e.g. the knowledge about sustainability can change when new discoveries through research emerges and new policies are necessary to formulate.

\section{DISCUSSION}

The purpose of this research paper was not to show empirical evidence supporting our arguments, but instead we attempted to explore and address the importance of sustainability indicators for IS and therefore generated a new set of sustainability indicators. This section will discuss our findings from the perspective of theoretical contributions. We believe these sets of new indicators for sustainability are interesting in different ways for organizations using IS.

Firstly, during the identification of the new indicators, economy was focused, which is very common to get diminished priority during sustainability and its evaluation. The proposed framework shows four layers of IS design, where under them, different indicators were categorized. Each design layer can be categorized under the three dimensions of sustainability, therefore technology, politics, and ethics were used as driving factors for transitions from one dimension to another. When conducting sustainability evaluation organizations often fail to connect different dimensions while making complex organizational decisions. It is impossible to summarize sustainability indicator [12], but Stockle et al. [27] suggested considering many indicators in the eval- uation. This can result in a focus on material driven sustainability and ignoring the associated information flows. Our framework can be a tool to resolve this problem since it connects two dimensions of sustainability in a process where different identified indicators are arranged. A call for bridging technology and policy making through the realization of the essential problems of sustainability during its quantification was addressed by Kharrazi et al. [20]. Our set of indicators organized in the proposed framework, thus supports this argument. Since the identified indicators by us are both subjective and objective in nature (Table 2), they can also be used to bridge the gap between "subjectivity and practicality" as argued also by Kharrazi et al. [20] to be a key requirement for increasing personal and organizational communications aiming for sustainability.

Secondly, the origin of our indicators traces us back to a challenging issue of UD. In our theoretical framework of Mustaquim and Nyström [24], UD principles were used to derive sustainable IT system design principles. The result from this paper could directly relate to the foundation of UD where it was seen from a new, broader perspective to be practiced outside the scope of accessibility issues. Using UD in the background in an advanced approach for finding out sustainability indicators and designing a framework, thus supports the argument made by Mustaquim and Nyström [25] where the authors argued towards the support of using UD in sustainability studies to explore sustainable HCI research domain and building new knowledge in design science and IS. This will raise the awareness of the complexity and multidimensionality of sustainability and give a higher chance of finding holistic solutions that will make an impact for the future generations.

Thirdly, the understanding of sustainability and its notion within the context of IS can be discoursed by our set of indicators and framework. One of the calls from Chen et al. [4] reflects the need of incorporating natural environment dimensions into IS research and our framework reflects this specific features and values by proposing a list of indicators that disclose environmental issues taken into account through economic and social issues for organizations. 
The complex process in the proposed framework and design space, therefore, supports the call for a subtle discourse by Mulvihill and Milan [23] towards an initiation of a holistic and universal meaning foundation for sustainability instead of several diverse meanings triggered by information technology.

We believe a number of interesting potential future researches could be initiated from the findings and extension of knowledge of this paper. First and foremost, the effectiveness of the indicators needs to be evaluated. The properties of good sustainability indicators should be assessed with respect to our proposed set of indicators. In addition, different existing sustainability schemes that are ready and available could be used as a checklist to analyze the effectiveness of our set of indicators for IS. In the long run this would also help structuring a dedicated checklist for IS community to evaluate sustainability. How the proposed set of indicators behaves if the source of data varies could be another interesting subject that is worth further exploring. The indicators could then be modified, refined and improved. Moreover, the proposed framework and the design space could be used as a methodological tool. Extensive empirical analysis is therefore required to claim the feasibility of using them as good design and analysis tool. Another important research could be studies associated with framing effect and persuasive design. The framing of a problem makes people decide differently [30]. How different framing of our identified indicators would influece user behavior in a message based persuasive design for sustainability could therefore be really interesting to observe. However, framing effect could also be studied to see how different framing of an indicator would result different user perceptions and thereby influence the result in quantification of sustainability. Finally, it would be interesting to see how a new IS could be designed by following the proposed design space. The sustainable behavior of such a system can then be compared with other IS that were not designed by following or consider our design space and indicators. The results from this paper could then take a new transfer for advancing knowledge.

\section{CONCLUSION}

We, in this paper have acknowledged a new set of sustainability indicators for IS that are constructed on previous sustainability studies. Followed by this we constructed a theoretical framework of selecting sustainability indicators for IS. A projected design space explained the different roles of these identified indicators in designing a sustainable IS. The lack of specified sustainability indicators for IS was the motivation behind this research work. The present focus on material driven sustainability is not enough and thus it is taking a major shift for the organizations. It is immensely becoming an important realization that the emphasis on sustainability needs a critical analysis by considering different associated information flows along with the materials. IS plays a critical role in this. In the near future, this could create a new competition for organizations that are using different ISs as a tool to achieve diverse sustainability goals. Measuring sustainability in a holistic way is therefore the key to compete in this challenge and concerning this, the proper choices of sustainability indicators would play the primary role. Sustainability is a huge driving factor and is significant for the future commercial success of different organizations who viably try to fulfill our diverse needs. While efficiency has usually been the primary focus on sustainability [3], our identified indicators, frameworks, and design space presented in this paper could highly contribute into the effectiveness of sustainability. Through this, an organization using IS in a future competitive sustainability market driven setup can distinguish and gain competitive advantages by enduring itself.

\section{REFERENCES}

[1] Azapagic, A., and Perdan, S. Indicators of sustainable development for industry: a general framework. Process Safety and Environmental Protection, 78(4), 2000, 243-261.

[2] Bossel, H. Deriving indicators of sustainable development. Environmental Modeling \& Assessment, $1(4), 1996,193-218$.

[3] Callens, I., and Tyteca, D. Towards indicators of sustainable development for firms: a productive efficiency perspective. Ecological Economics, 28(1), 1999, 41-53.

[4] Chen, A. J., Boudreau, M.-C., and Watson, R. T. Information systems and ecological sustainability. Journal of Systems and Information Technology, 10(3), 2008, 186-201.

[5] Cox, P. M., Betts, R. A., Jones, C. D., Spall, S. A., and Totterdell, I. J. Acceleration of global warming due to carbon-cycle feedbacks in a coupled climate model. Nature, 408(6809), 2000, 184-187.

[6] Dalsgaard, J. P., Lightfoot, C., and Christensen, V. Towards quantification of ecological sustainability in farming systems analysis. Ecological Engineering, 4(3), 1995, 181-189.

[7] Daly, H. E. Toward a steady-state economy. W.H. Freeman \& Company, San Francisco, 1973.

[8] Daly, H. E. Steady-state economics. Earthscan Publications Ltd, London, 1992.

[9] Devuyst, D., Hens, L., and De Lannoy, W. How green is the city?: sustainability assessment and the management of urban environments. Columbia University Press, New York, 2001.

[10] Farrell, A., and Hart, M. What does sustainability really mean?: The search for useful indicators. Environment: Science and Policy for Sustainable Development, 40(9), 1998, 4-31.

[11] Fiksel, J. Designing resilient, sustainable systems. Environmental science 85 technology, 37(23), 2003, 5330-5339.

[12] Flora, C. B. Building sustainable agriculture: a new application of farming systems research and extension. Journal of Sustainable Agriculture, 2(3), 1992, 37-49.

[13] Gallopín, G. C. Environmental and sustainability indicators and the concept of situational indicators. a systems approach. Environmental modeling $\mathcal{G}$ assessment, 1(3), 1996, 101-117.

[14] Gallopín, G. C. Indicators and their use: Information for decision-making. In Sustainability indicators, Report of the project on Indicators of Sustainable Development, SCOPE 58, B. Moldan and S. Bilharz, Eds. Wiley, Chicester, 1997, 13-27.

[15] Harger, J. R., and Meyer, F. M. Definition of indicators for environmentally sustainable development. Chemosphere, 33(9), 1996, 1749-1775. 
[16] Hemdi, A. R., Saman, M. Z., and Sharif, S. Sustainability evaluation using fuzzy inference methods. International Journal of Sustainable Energy, 32(3), 2013, 169-185.

[17] Herendeen, R. A. Energy analysis and emergy analysis -a comparison. Ecological Modelling, 178(1-2), 2004, 227-237.

[18] Hertel, M., and Wiesent, J. Investments in information systems: A contribution towards sustainability. Information Systems Frontiers, 15(5), 2013, 815-829.

[19] Hilty, L. M. Sustainable development and information technology. Environmental Impact Assessment Review, 22(5), 2002, 445-447.

[20] Kharrazi, A., Kraines, S., Hoang, L., and Yarime, M. Advancing quantification methods of sustainability: A critical examination emergy, exergy, ecological footprint, and ecological information-based approaches. Ecological Indicators, 37, 2014, 81-89.

[21] Maruster, L., Faber, N. R., and Peters, K. Sustainable information systems: a knowledge perspective. Journal of Systems and Information Technology, 10(3), 2008, 218-231.

[22] Meadows, D. H. Indicators and information systems for sustainable development. The Sustainability Institute, Hartland, 1998.

[23] Mulvihill, P. R., and Milan, M. J. Subtle world: Beyond sustainability, beyond information. Futures, 39(6), 2007, 657-668.

[24] Mustaquim, M., and Nyström, T. Designing sustainable it system -from the perspective of universal design principles. In UAHCI. Design Methods, Tools, and Interaction Techniques for eInclusion, C. Stephanidis and M. Antona, Eds., vol. 8009 of LNCS. Springer, Heidelberg, 2013, 77-86.

[25] Mustaquim, M., and Nyström, T. Designing information systems for sustainability -the role of universal design and open innovation. In Advancing the Impact of Design Science: Moving from Theory to Practice, M. Tremblay, D. VanderMeer,

M. Rothenberger, A. Gupta, and V. Yoon, Eds., vol. 8463 of $L N C S$. Springer International Publishing, Cham, 2014, 1-16.

[26] Stegall, N. Designing for sustainability: A philosophy for ecologically intentional design. Design Issues, 22(2), 2006, 56-63.

[27] Stockle, C. O., Papendick, R. I., Saxton, K. E., Campbell, G. S., and Van Evert, F. K. A framework for evaluating the sustainability of agricultural production systems. American Journal of Alternative Agriculture, 9(1-2), 1994, 45-50.

[28] Stott, P. A., Mitchell, J. F., Allen, M. R., Delworth, T. L., Gregory, J. M., Meehl, G. A., and Santer, B. D. Observational constraints on past attributable warming and predictions of future global warming. Journal of Climate, 19(13), 2006, 3055-3069.

[29] The Department of Economic and Social Affairs (DESA). Indicators of Sustainable Development: Guidelines and Methodologies, third ed. United Nations, New York, 2007.

[30] Tversky, A., and Kahneman, D. The framing of decisions and the psychology of choice. Science, 211(4481), 1981, 453-458.

[31] Wefering, F. M., Danielson, L. E., and White, N. M. Using the amoeba approach to measure progress toward ecosystem sustainability within a shellfish restoration project in north carolina. Ecological Modelling, 130(1), 2000, 157-166.

[32] Welford, R. Environmental Strategy and Sustainable Development: The Corporate Challenge for the Twenty-first Century. Routledge, 1995.

[33] Zufia, J., and Arana, L. Life cycle assessment to eco-design food products: industrial cooked dish case study. Journal of Cleaner Production, 16(17), 2008, 1915-1921. 